\title{
The Provision of Mathematics and Statistics Support in Scottish Higher Education Institutions (2017) - A Comparative Study by the Scottish Mathematics Support Network
}

Shazia Ahmed, Learning Enhancement and Academic Development Service (LEADS), University of Glasgow, Glasgow, Scotland. Email: Shazia.Ahmed@glasgow.ac.uk

Peter Davidson, Department of Mathematics \& Statistics, University of Strathclyde, Glasgow, Scotland. Email: Peter.Davidson@strath.ac.uk

Kate Durkacz, School of Engineering \& the Built Environment, Edinburgh Napier University, Edinburgh, Scotland. Email: K.Durkacz@napier.ac.uk

Calum Macdonald, School of Engineering \& Built Environment, Glasgow Caledonian University, Glasgow, Scotland. Email: Calum.Macdonald@gcu.ac.uk

Morgiane Richard, Centre for Academic Development, University of Aberdeen, Aberdeen, Scotland. Email: M.Richard@abdn.ac.uk

Alan Walker, School of Science \& Sport, University of West of Scotland, Paisley, Scotland.

Email: Alan.Walker@uws.ac.uk

\section{Abstract}

The Scottish Mathematics Support Network (SMSN) was formed in July 2008 with the aim of creating a support network for people working in Scottish universities who were involved with, or wished to be involved with, providing mathematical and/or statistical support for their students. The consensus of the SMSN is that increasingly more students need assistance with their basic mathematical and statistical skills than was the case in the past, and that consequently mathematics support is an area on which universities will need to focus on in future years. Through networking and professional development opportunities with other practitioners in the field of mathematics and statistics support, the SMSN have developed and maintained strong links with individual practitioners, and more broadly with like-minded groups such as the sigma Network and the Irish Mathematics Learning Support Network. With the provision of mathematics and statistics support becoming more prevalent in UK Higher Education institutions, it seemed timely to assess the current state of this provision in Scotland, and to compare with the rest of the British Isles. At the 2016 SMSN AGM, it was unanimously agreed that such a study should be carried out with the SMSN committee taking responsibility for conducting the research.

Keywords: Mathematics Support, Statistics Support, Higher Education, Scotland.

\section{Introduction}

While mathematics and statistics support in Higher Education (HE) across the UK and Republic of Ireland is a relatively recent development, with a little imagination, its origins can be traced back to the time of mathematicians such as Colin Maclaurin. As a Lecturer and Professor of Mathematics at the Universities of Aberdeen and Edinburgh in the early 18th Century, Maclaurin was described as being "kindly and approachable" and that the help he gave to his students "was never wanting, nor was admittance refused to any except in his teaching hours" (Chambers, 1875; O'Connor \& Robertson, 2017). However, at that time, only the privileged, and some particularly gifted students, were able to attend university so that there was little or no demand for any formal mathematics support.

In recent years, HE has made itself available to the wider population, with the number of UK universities more than doubling during the 1960s. Furthermore, with the introduction of post-1992 universities there are now around 160 universities in the UK (Higher Education Statistics Agency, 
2017). A consequence of this increase in degree-awarding institutions is that there has been a significant rise in student numbers. Additionally, UK governments have pledged financial support for widening access initiatives which has further contributed to the number of students in HE. In Scotland, these policies include articulation from the college sector that enables advanced entry to university, the Schools for Higher Education Programme (SHEP) which provides information, advice and guidance for schools across Scotland with traditionally low progression rates to $\mathrm{HE}$, and the Widening Access and Retention fund (WARF) which is awarded to the Scottish universities that have the highest widening access intake (Hunter Blackburn et al., 2016).

Consequently, universities have witnessed increasingly more entrants who come from diverse educational, social, and cultural backgrounds. The most recent UCAS report (UCAS Analysis and Research, 2017) showed that entry rates for students from the most deprived backgrounds in Scotland have reached the highest level on record. These students have widely varying experiences and knowledge of mathematics and statistics. Furthermore, the introduction of new degree programmes, such as computer games, digital security, computer networking and audio technology, has resulted in the need for students to learn mathematical topics on their degree courses that they possibly have not been adequately prepared for in school or the college sector.

\section{A Brief History of Mathematics Support in the UK and Ireland}

Although it is very difficult to provide an exact date and location as to when and where formal mathematics support in HE originated in the UK, three of the main institutions responsible for instigating formal support programmes were: in England, the Universities of Coventry, Hull and Loughborough (LTSN MathsTEAM, 2003b); and, in Scotland, Edinburgh Napier University (then, Napier Technical College). The latter, through the guidance of Ann Evans, initiated MathPlus in 1988 (Evans, 2010). This was one of the country's first mathematics drop-in centres. In England, the Mathematics and Statistics Support Service was established at Coventry University in 1991 with a grant from BP's Engineering Education Fund, while the University of Hull launched its service in 1995. Loughborough University opened its centre in 1996, targeting first year engineering students and offering a drop-in facility. From the mid-1990s, more universities across the UK started to offer mathematics and statistics support on a formal basis.

\subsection{Mathematics and Statistics Support in England \& Wales}

An important milestone in the development of mathematical and statistical support came in the early 2000s when the Learning and Teaching Support Network (LTSN) funded the LTSN MathsTEAM project. The project was a collaboration between four subject centres (LTSN Maths, Stats \& OR Network, LTSN Engineering, LTSN Physical Sciences, and the UK Centre for Materials Education). In 2003 three comprehensive booklets (LTSN MathsTEAM, 2003a; LTSN MathsTEAM, 2003b; LTSN MathsTEAM 2003c) were produced that focussed on case studies relevant to support for engineering and science students. The aim of the project was to enable the sharing of knowledge and materials and therefore promote good practice in the mathematical and statistical teaching and support community.

In the document Mathematics Support for Students (LTSN MathsTEAM, 2003b), it was observed that funding had been made available for the development of mathcentre, the first UK website of

\footnotetext{
* http://www.mathcentre.ac.uk/
} 
peer-reviewed mathematics support resources*. The facility came into existence in 2003 and was originally aimed at easing the transition of science and engineering students from school to university. Over the years it has grown into an extensive online resource, with well over 22,000 visitors each month (Matthews \& Croft, 2011). mathcentre offers lecture notes, audio and visual tutorials, exercises and diagnostic tests. The Engineering Council (UK) in June 2000 recommended to all universities that students embarking on a mathematics-based degree should take a diagnostic test on entry (LTSN MathsTEAM, 2003b).

The MathsTEAM study reported that staff at over 20 institutions across the UK discussed various aspects of their work including how their centre was formed, the barriers and enablers encountered and what support was needed from the university and its staff. They also provided evidence of the level of success achieved, mainly in terms of the number of students using the facility, and offered advice on how others could establish a support network.

Lawson, Halpin \& Croft (2001) noted that there was already extensive provision of mathematics support centres across the UK, with $48 \%$ of the 95 institutions who replied to their survey indicating that they had some form of mathematics support. Two further surveys undertaken in 2004 (Perkin \& Croft, 2004) and 2012 (Perkin, Lawson \& Croft, 2012) identified considerable growth in mathematics support in the HE sector. Table 1 summarises the findings.

Table 1: Summary of mathematics support provision across the UK in 2000, 2004 and 2012 (adapted from Lawson, Halpin \& Croft, 2001; Perkin \& Croft, 2004; and, Perkin, Lawson \& Croft, 2012).

\begin{tabular}{|c|c|c|c|}
\hline Year of Survey & $\begin{array}{c}\text { Number of HEIs } \\
\text { replying to survey }\end{array}$ & $\begin{array}{c}\text { Number of HEls } \\
\text { providing support } \\
\text { (of respondents) }\end{array}$ & $\begin{array}{c}\text { Percentage } \\
\text { offering support } \\
\text { (of respondents) }\end{array}$ \\
\hline 2000 & 95 & 46 & 48 \\
\hline 2004 & 101 & 66 & 65 \\
\hline 2012 & 103 & 88 & 85 \\
\hline
\end{tabular}

The level of support available, as noted by Perkin, Lawson \& Croft (2012), varies considerably between institutions, with some centres staffed by academics open seven days a week while others restrict opening to a few hours per week with staffing by postgraduates. The target groups also vary across universities, with some offering support to all students (and staff) while others restrict availability to first year undergraduates only.

Following a collaborative bid to the Higher Education Funding Council for England (HEFCE) in 2005, Coventry and Loughborough Universities were awarded the Centre for Excellence in Teaching and Learning (CETL) status. As a result, the sigma CETL project was launched to promote collaborative work in mathematics and statistics support on a national basis, and received funding from the HEFCE until 2010.

In 2010, the sigma CETL project became the sigma project and received a 2-year funding commitment from the National HE STEM programme. In 2012, the sigma Network was created for

* See the paper 'Review a legacy resource: a new feature in MSOR Connections to aid discovery of hidden gems' in this issue (p. 55) for discussion about increasing the visibility of resources from legacy projects - Ed. 
those working in mathematics support in England and Wales. Further support from HEFCE between 2013 and 2016 has helped fund new mathematics support centres, run workshops and conferences and undertake various related activities (The sigma Network, 2013).

\subsection{Mathematics and Statistics Support in the Republic of Ireland}

In the Republic of Ireland, the first mathematics support centre was opened at the University of Limerick in late 2001 with funding coming from the Higher Education Academy (HEA). A form of mathematics support had however been in place at the university since 1997. This facility was created in response to concerns regarding the mathematical ability of many students entering the first year of programmes which involved an element of mathematics service teaching.

In 2008, the Centre for Excellence in Mathematics Teaching and Learning (CEMTL) undertook a comprehensive audit (Gill, O'Donoghue \& Johnson, 2008) of 13 third level Irish HE institutions. The associated report was the first of its type on Irish mathematics support. It aimed to provide a summary of available resources, as well as identifying challenges faced by staff, and making recommendations for the efficient operation of mathematics support centres.

The Irish Mathematics Learning Support Network (IMLSN) was formed in 2009 and provides a forum for those in the island of Ireland as a whole who are involved in mathematics support as well as providing an avenue for collaboration with UK counterparts. An in-depth survey of mathematics support provision across the island of Ireland was carried out in 2015 (Cronin et al., 2016) and found that the level of provision compared favourably with that in the UK and Australia. A selection of the report's findings is presented in Section 4: Comparison with UK and Ireland.

\subsection{Mathematics and Statistics Support in Scotland}

The Scottish Mathematics Support Network (SMSN) was created in July 2008 with the aim of initialising a support network for people working in Scottish universities (and colleges) who were either currently providing, or would like to provide, mathematical and/or statistical support to their undergraduate and postgraduate students.

The inaugural meeting of the SMSN was funded by sigma, and included a presentation by Professor Tony Croft, then Director of the Mathematics Education Centre at Loughborough University. Representatives from seven Scottish institutions were in attendance. The consensus at the meeting was that more students were in need of assistance with their basic mathematical and statistical skills than in the past, and that mathematics support was an area on which universities needed to focus on in future years.

In turn, the Scottish universities that provide mathematics and/or statistics support have hosted an annual meeting, and the membership of the network has increased steadily since 2008. In addition, the SMSN have also run themed events, such as LaTeX workshops, which have been of interest to the Scottish mathematics support community as a whole.

Through these networking and professional development opportunities with other practitioners in the field of mathematics and statistics support, the SMSN have developed and maintained strong links with individual practitioners, and more broadly with like-minded groups such as the sigma Network and the Irish Mathematics Learning Support Network.

\section{Methodology}

Representatives from all Scottish universities were invited to the 2016 SMSN Annual Meeting, and the meeting was attended by delegates from eight Scottish universities: Aberdeen, Abertay, Dundee, 
Edinburgh Napier, Glasgow, Glasgow Caledonian, Robert Gordon and Strathclyde, alongside speakers from Loughborough University and Keele University. At this meeting, the provision of mathematics and statistics support becoming more prevalent in UK Higher Education Institutions was discussed. It was unanimously agreed that a study on the provision of mathematics and statistics support at Scottish Higher Education institutions (a list of institutions can be found in appendix A) should be implemented, with the SMSN committee taking responsibility for conducting the research. This study was aimed at accurately measuring the types of support available, how support was staffed, what facilities were in use and how the Scottish institutions compared with those of the British Isles as a whole. During the meeting, a research questionnaire was devised, based on the questionnaire used by IMLSN for their 2015 audit (Cronin et al., 2016), and ratified by attendees. The questionnaire mainly consisted of closed questions with multiple-option set responses (a copy of the questionnaire is included in appendix B). The questionnaire was then completed by a representative from each institution stated above and an online version was made available to those who were not present at the meeting. Once the results had been collated, the SMSN committee members reflected on the original questionnaire and agreed to contact the respondents who had stated that their institutions offered mathematics and/or statistics support with a follow-up questionnaire. This questionnaire focussed on the location of support sessions, the funding provided, and how the support service could be improved.

\section{Summary of Findings}

Responses to the questionnaire were received from all but two Scottish Higher Education Institutions. The Open University in Scotland, and Scotland's Rural College did not provide responses, although it is unclear as to whether or not mathematics and/or statistics support would be required or relevant in these institutions. In response to questions about whether mathematics and/or statistics support was provided, the data in Table 2 was collated.

From the data in Table 2, it can be seen that more than three quarters of Scottish institutions provide mathematics and/or statistics support; four institutions do not offer any support. Of those providing support, a total of $46 \%$ offer both mathematics and statistics support, $23 \%$ offer mathematics support only and $8 \%$ offer statistics support only. One institution did not indicate which area(s) support was provided for.

The data shows that the mechanisms for providing support vary between the institutions and include dedicated members of staff, graduate teaching assistants (GTAs), undergraduate teaching assistants (UGTAs) and mathematics lecturers. The equivalent FTE for each institution is shown in the final column, if this information was given. The estimated total number of hours of support provided per year across all institutions exceeds 7,644.

Various types of support are offered, including drop-in sessions, bookable one-to-one appointments, workshops and online support. These may be available for all students, undergraduate and postgraduate, or may be restricted to undergraduates, or to students in particular departments. In some cases, the support is available for staff. Support may be offered online or in dedicated space or shared space, and in some institutions support can be booked through a central booking system. A summary of provision is shown in Table 3.

From the data in Table 3, it can be seen that the most popular modes of delivery are one-to-one support and drop-in sessions, which are offered by $77 \%$ of the institutions having a support provision. Online support, which includes use of social media, is available at $62 \%$ of institutions and workshops are the least popular at 54\%. Most institutions have more than one delivery mode, with only three (23\%) having a single mode. Ten institutions support both undergraduate and postgraduate students, but only five of these include support for postgraduate researchers. Three institutions also 
support staff, but of these only one supports staff in statistics. Three institutions only support undergraduates. Attendance is recorded at nine of the institutions.

Table 2: Mathematics and/or statistics support and staffing.

\begin{tabular}{|c|c|c|c|c|c|}
\hline Institution & Support & $\begin{array}{l}\text { Dedicated } \\
\text { Staff }\end{array}$ & $\begin{array}{l}\text { GTA }^{4} \\
\text { Available }\end{array}$ & $\begin{array}{l}\text { Other } \\
\text { Information }\end{array}$ & $\begin{array}{l}\text { Total } \\
\text { FTE }\end{array}$ \\
\hline $\begin{array}{l}\text { Edinburgh Napier } \\
\text { University }\end{array}$ & Yes & No & No & $\begin{array}{l}\text { Part of } \\
\text { Mathematics } \\
\text { lecturers' } \\
\text { workloads }\end{array}$ & 0.5 \\
\hline $\begin{array}{l}\text { Glasgow Caledonian } \\
\text { University }\end{array}$ & Yes & Both $^{1}$ & No & - & 1 \\
\hline Glasgow School of Art & No & - & - & - & - \\
\hline Heriot-Watt University & No & No & No & - & - \\
\hline $\begin{array}{l}\text { Inverness College } \\
\text { (University of } \\
\text { Highlands and Islands) }\end{array}$ & Yes & Mathematics $^{2}$ & No & - & 0.2 \\
\hline $\begin{array}{l}\text { Queen Margaret } \\
\text { University }\end{array}$ & No & No & - & - & - \\
\hline $\begin{array}{l}\text { Robert Gordon } \\
\text { University }\end{array}$ & Yes & Both & No & $\begin{array}{l}\text { Additional } \\
\text { help from } \\
\text { Mathematics } \\
\text { lecturers }\end{array}$ & 1 \\
\hline $\begin{array}{l}\text { The Royal } \\
\text { Conservatoire of } \\
\text { Scotland }\end{array}$ & No & - & - & - & - \\
\hline University of Aberdeen & Yes & Both & No & - & 0.5 \\
\hline University of Abertay & Yes & Statistics $^{3}$ & Statistics & - & 0.6 \\
\hline University of Dundee & Yes & No & No & Limited & Ad hoc \\
\hline University of Edinburgh & Yes & Both & Both & - & Ad hoc \\
\hline University of Glasgow & Yes & Mathematics & Statistics & - & 1.08 \\
\hline $\begin{array}{l}\text { University of St } \\
\text { Andrews }\end{array}$ & Yes & No & Both & - & Ad hoc \\
\hline University of Stirling & Yes & No & No & $\begin{array}{l}\text { Provided by } \\
\text { a lecturer }\end{array}$ & - \\
\hline $\begin{array}{l}\text { University of } \\
\text { Strathclyde }\end{array}$ & Yes & Both & No & $\begin{array}{l}\text { UG Teaching } \\
\text { Assistants }\end{array}$ & 1 \\
\hline $\begin{array}{l}\text { University of the West } \\
\text { of Scotland }\end{array}$ & Yes & No & Mathematics & $\begin{array}{l}\text { Provided by } \\
\text { Physics PGs }\end{array}$ & - \\
\hline
\end{tabular}

${ }^{1}$ Both means that the Institution has dedicated staff for both Mathematics and Statistics support.

${ }^{2}$ Mathematics means that dedicated staff is for Mathematics only.

${ }^{3}$ Statistics means that dedicated staff is for Statistics only.

${ }^{4}$ GTA: Graduate Teaching Assistant. 
Table 3: Type of support and participants.

\begin{tabular}{|l|c|c|c|c|c|c|c|c|}
\hline Institution & $\mathbf{1 - 1}$ & Drop In & Workshop & Online & UG & PGT & PGR & Staff \\
\hline $\begin{array}{l}\text { Edinburgh Napier } \\
\text { University }\end{array}$ & & $\mathrm{Y}$ & & $\mathrm{Y}$ & $\mathrm{Y}$ & $\mathrm{Y}$ & & \\
\hline $\begin{array}{l}\text { Glasgow Caledonian } \\
\text { University }\end{array}$ & $\mathrm{Y}$ & $\mathrm{Y}$ & $\mathrm{Y}$ & $\mathrm{Y}$ & $\mathrm{Y}$ & $\mathrm{Y}$ & $\mathrm{Y}$ & $\mathrm{Y}$ \\
\hline Glasgow School of Art & & & & & & & & \\
\hline Heriot-Watt University & & & & & & & & \\
\hline $\begin{array}{l}\text { Inverness College } \\
\text { (University of Highlands } \\
\text { and Islands) }\end{array}$ & & $\mathrm{Y}$ & & & $\mathrm{Y}$ & $\mathrm{Y}$ & $\mathrm{Y}$ & \\
\hline Queen Margaret University & & & & & & & & \\
\hline Robert Gordon University & $\mathrm{Y}$ & $\mathrm{Y}$ & $\mathrm{Y}$ & & $\mathrm{Y}$ & $\mathrm{Y}$ & & \\
\hline $\begin{array}{l}\text { The Royal Conservatoire } \\
\text { of Scotland }\end{array}$ & & & & & & & & \\
\hline University of Aberdeen & $\mathrm{Y}$ & $\mathrm{Y}$ & $\mathrm{Y}$ & $\mathrm{Y}$ & $\mathrm{Y}$ & $\mathrm{Y}$ & $\mathrm{Y}$ & $\mathrm{Y}$ \\
\hline University of Abertay & $\mathrm{Y}$ & $\mathrm{Y}$ & $\mathrm{Y}$ & $\mathrm{Y}$ & $\mathrm{Y}$ & $\mathrm{Y}$ & $\mathrm{Y}$ & \\
\hline University of Dundee & $\mathrm{Y}$ & & & & $\mathrm{Y}$ & & & \\
\hline University of Edinburgh & $\mathrm{Y}$ & $\mathrm{Y}$ & $\mathrm{Y}$ & $\mathrm{Y}$ & $\mathrm{Y}$ & & & \\
\hline University of Glasgow & $\mathrm{Y}$ & $\mathrm{Y}$ & $\mathrm{Y}$ & $\mathrm{Y}$ & $\mathrm{Y}$ & $\mathrm{Y}$ & & \\
\hline University of St Andrews & $\mathrm{Y}$ & & & $\mathrm{Y}$ & $\mathrm{Y}$ & $\mathrm{Y}$ & & \\
\hline University of Stirling & $\mathrm{Y}$ & & $\mathrm{Y}$ & & $\mathrm{Y}$ & $\mathrm{Y}$ & $\mathrm{Y}$ & $\mathrm{Y}$ \\
\hline University of Strathclyde & $\mathrm{Y}$ & $\mathrm{Y}$ & & $\mathrm{Y}$ & $\mathrm{Y}$ & $\mathrm{Y}$ & & \\
\hline $\begin{array}{l}\text { University of the West of } \\
\text { Scotland }\end{array}$ & & $\mathrm{Y}$ & & & $\mathrm{Y}$ & & & \\
\hline
\end{tabular}

Three additional questions were sent to the institutions offering mathematics and/or statistics support. These questions focussed on the location of support sessions, the funding provided, and how the support service could be improved. Overall, $62 \%$ of responses were received to these subsequent questions. It was found that there were three different types of teaching space utilised, these being: dedicated space, shared space with other discipline's support groups, and centrally bookable rooms. The three types of location were available in equal amount across the institutions, with three institutions having access to all arrangements and one having a dedicated space for statistics only. With regards to funding, it was found that $46 \%$ of the support services were allocated funding from a central source, $15 \%$ from a departmental funding source, and a further $15 \%$ came from ad-hoc payments. All the institutions commented that improvements could be made to their services by either an increase in staff numbers, or access to dedicated space, or both. It should be noted, of course, that both of these proposed improvements would require an injection of funding for them to be realised.

The data garnered, however, does not evidence the effectiveness of such delivery modes. Evaluation of these is difficult due to the many factors which impact upon a student's ability to succeed (Matthews et al., 2013). Therefore, anecdotal evidence aside, how one could accurately measure the effectiveness of these delivery modes remains to be seen. While there are obvious benefits of one-to-one sessions with students, there is a cost versus reward argument which would be made by both the budget holders and the student retention officers. Drop-in sessions, being the second most popular delivery mode, have the disadvantage of often being held on Wednesday afternoons, when they are in direct competition with sports clubs and/or students' part time employment. Nevertheless, the uptake of these sessions, particularly immediately before module examinations, is evidence as to their popularity, if not their usefulness. Finally, while online support 
would mostly always be available, it can be argued that it is not as effective as it does not provide the intangible benefits which relate to the in-person communication available in one-to-one and dropin sessions. In spite of the range of available delivery modes, there is still a persistent minority of students who would benefit from the available support who do not make use of it (Symonds, Lawson \& Robinson, 2008).

Even though evaluation of efficacy of mathematics and statistics support is difficult, as noted above, one study has been conducted in Scotland. At Glasgow Caledonian University an attempt has been made to quantify the success of mathematics support by comparing the module performance of two groups of undergraduate students: those who engage with mathematics support and their counterparts who choose not to engage. The module marks achieved by students, across all undergraduate levels, were selected as a measure of how mathematical support impacts on student performance. Data were collected for computing and engineering students, in the School of Engineering and Built Environment, studying modules with a substantial mathematical content as part of their degree programme. The study showed (Macdonald, 2014) that there was substantial and significant difference between the average marks achieved by engaging and non-engaging students. Students who engaged with mathematical support on average showed an $8 \%$ increase in their module mark compared with those who did not engage.

A summary of the availability of mathematics and/or statistics provision in Scottish HEls has been presented on an interactive map", created by the SMSN. A green tag represents institutions with both mathematics and statistics support provision, an orange tag represents institutions with either mathematics or statistics support provision, and a red tag represents institutions with neither mathematics nor statistics support provision.

\section{Comparison with UK and Ireland}

The most recent Irish Mathematics Learning Support Network (IMLSN) audit of mathematics support in Ireland was conducted in 2015 (Cronin et al., 2016) following a similar survey in 2008 (Gill, O'Donoghue \& Johnson, 2008). Members of the National HE STEM programme conducted a UK wide survey in 2012 (Perkin, Lawson \& Croft, 2012; Perkin, Lawson \& Croft, 2013) and the sigma Network is in the process of designing and conducting a new survey in England and Wales.

The 2015 island of Ireland survey consisted of 58 questions sent to 31 institutions in Northern Ireland and the Republic of Ireland, including universities, institutes of technology, colleges of education and liberal arts, and colleges of further and higher education. Results of the survey are bracketed under six main themes: availability and practical operation of mathematics learning support, staffing and tutors, types of support available, users of the service, reporting and evaluation of activities, challenges and developments.

Authors of the 2012 UK survey contacted 119 universities in England, Scotland, Wales and Northern Ireland with three questions that asked the extent of mathematics and/or statistics support available, whether papers are published to describe or evaluate the support provision offered, and whether the institution provides any engineering education support. The institutions that responded to the survey were categorised by their 'mission group': Russell Group, 1994 Group, University Alliance, million+, Cathedrals Group, Unaligned Universities.

* The map has been made available at https://drive.google.com/open?id=1TkLfxHQbVlj WIWdwe-JphgS1c4. 
The response rates of the 2016 SMSN, 2015 IMLSN and 2012 UK surveys are detailed in Table 4.

Table 4: Response rates of the 2016 SMSN, 2015 IMLSN and 2012 UK surveys.

\begin{tabular}{|c|c|c|c|}
\hline Survey & Institutions Contacted & Institutions Responded & Percentage \\
\hline SMSN & 19 & 17 & $89 \%$ \\
\hline IMLSN & 31 & 30 & $97 \%$ \\
\hline UK & 119 & 103 & $87 \%$ \\
\hline
\end{tabular}

We compare the results of the IMLSN and UK surveys with the SMSN findings but note that there are two key differences between the three surveys. Firstly, authors of the SMSN and UK surveys contacted only universities while the results of the IMLSN survey also included data from colleges and institutes of technology. Secondly, the questions in the IMLSN survey focussed exclusively on the provision of mathematics support while the SMSN and UK studies also included questions concerning support for statistics.

Mathematics and/or statistics support existed in 13 of the 17 universities (76\%) that responded to the SMSN survey. This figure compares to $85 \%$ of the universities in the UK survey and $83 \%$ of the institutions that completed the IMLSN survey. Out of the 4 Scottish institutions that did not offer mathematics and/or statistics support, two are the Glasgow School of Art and the Royal Conservatoire of Scotland. It is not expected that such institutions would offer learning support of this nature and hence if these institutions are excluded from the SMSN data, then the extent of support provision in Scotland is $87 \%$, which is commensurate with Ireland and the UK as a whole.

Differences in the support provision offered in Scotland, Ireland and the UK are detailed in Table 5 below. It is interesting to note that drop-in support and one-to-one appointments are available in equal measure throughout institutions in Scotland, while drop-in services are much more popular in Ireland and the UK (overwhelmingly so in the latter case). Workshops or optional classes are offered in $55 \%$ of institutions in Scotland and $64 \%$ in Ireland, but only occurred in $8 \%$ of institutions in the UK in 2012. The provision of online support is highest in Scotland with $73 \%$ of institutions offering such support compared with 48\% in Ireland. However, it should be noted that the 2012 UK survey did not explicitly ask if online support was available and of the 13 institutions that did not offer online learning support in Ireland, 69\% were planning to implement this.

Table 5: Comparisons of learning support provision in Scotland, UK and Ireland.

\begin{tabular}{|l|c|c|c|}
\hline & Scotland $(\mathbf{n = 1 3})$ & UK (n=103) & Ireland (n=25) \\
\hline Drop-in service offered & $76 \%$ & $84 \%$ & $88 \%$ \\
\hline $\begin{array}{l}\text { 1-1 appointments } \\
\text { available }\end{array}$ & $76 \%$ & $6 \%$ & $44 \%$ \\
\hline $\begin{array}{l}\text { Workshops or optional } \\
\text { classes offered }\end{array}$ & $54 \%$ & $8 \%$ & $64 \%$ \\
\hline Online Support & $61 \%$ & - & $48 \%$ \\
\hline
\end{tabular}

Out of the 13 institutions that offered mathematics and/or statistics learning support in Scotland, 9 were staffed by either full-time tutors, lecturers or dedicated teaching staff (collectively referred to as FTE staff), while 8 provided support by postgraduate students. It is quite common to find universities in Scotland using a combination of these staff profiles and a similar picture is found in Ireland where the authors of the IMLSN survey found that $48 \%$ of institutions used staff from a variety of sources. Only one university in Scotland, the University of Strathclyde, employed the use of undergraduate 
teaching assistants compared with $36 \%$ of institutions in Ireland. A complete breakdown of this data, together with results from the 2012 UK survey, is given in Table 6.

Table 6: Comparison of staff profiles in institutions offering learning support.

\begin{tabular}{|l|c|c|c|}
\hline & Scotland (n=13) & UK (n=103) & Ireland (n=25) \\
\hline $\begin{array}{l}\text { Support offered by FTE } \\
\text { staff }\end{array}$ & $69 \%$ & $86 \%$ & $72 \%$ \\
\hline $\begin{array}{l}\text { Support offered by } \\
\text { postgraduate students }\end{array}$ & $61 \%$ & $14 \%$ & $48 \%$ \\
\hline $\begin{array}{l}\text { Support offered by } \\
\text { undergraduate students }\end{array}$ & $8 \%$ & - & $36 \%$ \\
\hline
\end{tabular}

Fewer institutions (54\%) in Scotland offered mathematics and/or statistics learning support from a dedicated space than in Ireland (80\%). However, there are more cases in Ireland of this space being shared with other academic support units (63\% in Ireland compared with $31 \%$ in Scotland).

In terms of funding, $54 \%$ of institutions in Ireland were funded centrally while academic departments were responsible for funding in $29 \%$ of cases. In Scotland, $46 \%$ of universities fund mathematics and/or statistics support centrally, $15 \%$ provide funding through departments or student services and $15 \%$ are funded on an ad hoc basis. We note that six institutions did not provide any information regarding their funding position. Also, some support facilities use a blended approach, with dedicated staff funded centrally and ad hoc funding for additional tutors. Funding information was not included in the 2012 UK survey.

Table 7: Funding and availability of space in Scottish and Irish learning support facilities.

\begin{tabular}{|l|c|c|}
\hline & Scotland (n=13) & Ireland (n=25) \\
\hline Dedicated Space & $54 \%$ & $80 \%$ \\
\hline Shared Space & $31 \%$ & $63 \%$ \\
\hline Centrally Funded & $46 \%$ & $54 \%$ \\
\hline $\begin{array}{l}\text { Departmental } \\
\text { Funding }\end{array}$ & $15 \%$ & $29 \%$ \\
\hline Ad hoc Funding & $15 \%$ & - \\
\hline
\end{tabular}

The SMSN survey asked respondents to comment on improvements to their support facilities that they would like to see implemented. The three most common replies (in order of preference) were: an increase in staff numbers, an increase in funding for resources and equipment, and a dedicated space. It is interesting to note that these comments matched the most common improvement themes reported in the IMLSN survey. These were: location and space, support and materials, and tutors. Many institutions reported a need for dedicated and larger space, resources to provide specialised workshops, and more tutors. Two institutions in Ireland reported that dedicated staff for statistics and engineering would be desirable, matching similar comments from two institutions in Scotland.

\section{Conclusions and Discussion}

Since the higher education boom in the 1960s and the introduction of post-1992 universities, student numbers in the United Kingdom have increased to unprecedented levels. In addition, the introduction of policies aimed at increasing student numbers from the country's most deprived areas have meant that universities have witnessed increasingly more entrants who come from diverse educational, 
social, and cultural backgrounds. The current population of university students have widely varying experiences and knowledge of mathematics and statistics, and an extensive range of mathematical and statistical requirements. Consequently, the need, and use, of mathematics and statistics support provision has risen considerably.

In this paper, the strengths and weaknesses of the support provision available in Scotland are highlighted and benchmarked against the UK and the island of Ireland. It was found that there is strong provision of support for undergraduate and postgraduate students, but a perceived poor availability for postgraduate researchers and staff. The percentage of institutions offering support is comparable across the three groups, but with Scotland offering considerably more pre-arranged oneto-one support over its UK and Ireland counterparts. A comparable percentage of Scottish and Irish institutions offer workshops or specialised classes, and these numbers far exceed the percentage of UK institutions offering these options. Furthermore, the availability of online support for Scottish students slightly outperforms that of Irish institutions, with no UK data available.

It was observed that all three groups have a similar proportion of institutions which make use of FTE staff, but proportionally more Scottish institutions rely on postgraduate tutors, and proportionally more Irish institutions rely on undergraduate tutors. However, it is noted that the Irish institutions boast a significantly larger number of dedicated and shared support provision space, even though the funding avenues are not dissimilar.

The perceived issues with mathematics and statistics support in Scotland, the UK, and the island of Ireland are comparable. That is, the number of tutors, the provision available, and the space in which to avail oneself of these aforementioned factors, is paramount across the regions.

In conclusion, the Scottish institutions are certainly comparable with, and sometimes outperforming (at least in availability), the institutions of the entire UK, and the island of Ireland. However, it is clear that Scottish institutions are required to invest more in dedicated space for students who are in need of additional mathematics and statistics support. Given the recent success of the inaugural Maths Week Scotland, it is hoped that Scottish universities appreciate the breadth of mathematical and statistical applications in today's degree programmes and provide appropriate funding to support the ever-changing demands of students in Scotland. 


\section{Appendices}

Appendix A - List of Institutions

University of Aberdeen

University of Abertay

University of Dundee

University of Edinburgh

Edinburgh Napier University

University of Glasgow

Glasgow Caledonian University

Glasgow School of Art

Heriot Watt University

University of Highlands \& Islands (Inverness College)

Open University in Scotland

Queen Margaret University

Robert Gordon University

Royal Conservatoire of Scotland

Scotland's Rural College

University of St Andrews

University of Stirling

University of Strathclyde

University of West of Scotland 
Name:

Role:

Institution:

1. Does your institution offer Mathematics and/or Statistics support?

YES (please go to question 3)

NO (please go to question 2)

2. If NO, please give reason. Tick all that apply.

Mathematics /Statistics support not required

Lack of funding

Lack of support from senior management

Other - please give details overleaf

\section{(END OF QUESTIONNAIRE)}

3. If YES, please give details of staffing. Tick all that apply

Dedicated staff for Mathematics \& Statistics support

Dedicated staff for Mathematics support only

Dedicated staff for Statistics support only

Postgraduate students (GTAs) for Mathematics support

Postgraduate students (GTAs) for Statistics support

Other - please give details overleaf

4.
a) Please state total FTE for Mathematics \& Statistics support
b) Please state total FTE for Mathematics support only
c) Please state total FTE for Statistics support only

5. What type of support is on offer? Tick all that apply.

1-1 appointments

Drop-in sessions

Targeted lectures/workshops

Online

Other - please give details overleaf

6. Do you keep attendance records? Delete as appropriate.

Yes

No

7. Who can use the service? Tick all that apply.
UG
PGT
PGR
Staff

Other - please give details

8. Which is the largest user group(s)?

9. Any other comments? Please give details overleaf.

\section{(END OF QUESTIONNAIRE)}




\section{References}

Chambers, R., 1875. Maclaurin. In: T. Thomson, A bibliographical dictionary of eminent Scotsmen (Volume 3). Glasgow: Blackie and son. pp. 64-69.

Cronin, A., Cole, J., Clancy, M., Breen, C. and Ó Sé, D., 2016. An audit of mathematics learning support provision on the island of Ireland in 2015, Dublin: National Forum for the Enhancement of Teaching and Learning in Higher Education. Available at:

https://pure.qub.ac.uk/portal/files/135272903/MLS Ireland survey 2015.pdf [Accessed 17/01/2018].

Evans, A., 2010. MathsPlus at Edinburgh Napier: The first 22 years. In: 2nd Annual Scottish Maths Support Network Meeting. Edinburgh Napier University, 11 June 2010. Available at: https://sites.google.com/site/scottishmsn/events/2010 [Accessed 17/01/2018].

Gill, O., O'Donoghue, J. \& Johnson, P., 2008. An audit of mathematics support provision in Irish third level institutions. Limerick: Regional Centre for Excellence in Mathematics Teaching and Learning. Available at: https://www3.ul.ie/cemt//pdf\%20files/FullAudit.pdf [Accessed 17/01/2018].

Higher Education Statistics Agency, 2017. Introduction - Students 2015/16. Available at: https://www.hesa.ac.uk/data-and-analysis/publications/students-2015-16/introduction [Accessed 17/01/2018].

Lawson, D., Halpin, M. and Croft, T., 2001. After the diagnostic test - what next?. MSOR Connections, 1(3), pp. 19-23.

LTSN MathsTEAM, 2003a. Diagnostic testing for mathematics. Learning and Teaching Support Network. Available at: http://www.sigma-network.ac.uk/ltsn-mathsteam-project-guides/ [Accessed 17/01/2018].

LTSN MathsTEAM, 2003b. Mathematics support for students. Learning and Teaching Support Network. Available at: http://www.sigma-network.ac.uk/ltsn-mathsteam-project-guides/ [Accessed 17/01/2018].

LTSN MathsTEAM, 2003c. Maths for engineering and science. Learning and Teaching Support Network. Available at: http://www.sigma-network.ac.uk/ltsn-mathsteam-project-guides/ [Accessed 17/01/2018].

Macdonald C.A., 2014. Maths Support at Glasgow Caledonian University. In: 6th Annual Scottish Maths Support Network Meeting, University of Dundee, 20 June 2014. Available at: https://sites.google.com/site/scottishmsn/events/2014 [Accessed 19/04/2018].

Matthews, J. \& Croft, T., 2011. Sharing Mathematics Support Resources - the mathcentre Community Project, MSOR Connections, 11(2), pp. 37-39.

Matthews, J., Croft, A.C., Lawson, D.A. and Waller, D., 2013. Evaluation of mathematics support centres: a literature review. Teaching Mathematics and Its Applications, 32(4), pp. 173-190. https://doi.org/10.1093/teamat/hrt013.

O'Connor, J.J. and Robertson, E.F., 2017. Colin Maclaurin. Available at: http://www-groups.dcs.stand.ac.uk/history/Biographies/Maclaurin.html [Accessed 17/01/2018]. 
Perkin, G. and Croft, A.C., 2004. Maths Support Centres - the extent of current provision. MSOR Connections, 4(2), pp. 14-18.

Perkin, G., Lawson, D. and Croft, A.C., 2013. Mathematics learning support in UK higher education - the survey 2012. Teaching Mathematics and Its Applications, 32(4), pp. 165-172.

https://doi.org/10.1093/teamat/hrt014.

Perkin, G., Lawson, D. and Croft, T., 2012. Mathematics learning support in UK higher education: the extent of provision in 2012. Loughborough: Loughborough University on behalf of the National HE STEM Programme. Available at: http://www.mathcentre.ac.uk/resources/uploaded/52789-mlsin-uk.pdf [Accessed 17/01/2018].

The sigma Network, 2013. The sigma Network. Available at: http://www.sigmanetwork.ac.uk/about/the-sigma-network/ [Accessed 17/01/2018].

Symonds, R., Lawson, D.A. and Robinson, C., 2008. Promoting student engagement with mathematics support. Teaching Mathematics and Its Applications, 27(3), pp. 140-149.

https://doi.org/10.1093/teamat/hrn011.

UCAS Analysis and Research, 2017. End of cycle report 2017: Executive summary. Cheltenham: Universities and Colleges Admissions Service. Available at:

https://www.ucas.com/file/140436/download?token=WX45D1IF [Accessed 17/01/2018].

Hunter Blackburn, L., Kader-Satat, G., Riddell, S. and Weedon, E., 2016. Access in Scotland: Access to higher education for people from less advantaged backgrounds in Scotland. London: The Sutton Trust. Available at: https://www.suttontrust.com/wp-content/uploads/2016/05/Access-inScotland May2016-1.pdf [Accessed 17/01/2018]. 